\title{
The Formation of the Profile of the Competencies of the Principal of Municipal Educational Institution
}

\author{
Irina P. Vorontsova* \\ Siberian Federal University \\ 79 Svobodny, Krasnoyarsk, 660041, Russia
}

Received 01.06.2015, received in revised form 12.08.2015, accepted 30.09.2015

The paper presents the results of the research on the formation of the profile of competencies of the head of the municipal educational institution using the methodology QPD (Questionnaire Profiles of Demands) and of Computer Aided Personnel Test (CAPTain), which allows determining the threshold characteristics of a number of criteria of readiness to perform the work. The study was sponsored by Krasnoyarsk regional fund for supporting scientific research and technical research activities, project "Development of the corruption card of the head of the municipal educational institution (MEI)".

Keywords: competencies, educational institution, profile of competences, assess-ment and monitoring of competencies.

DOI: $10.17516 / 1997-1370-2015-8-11-2275-2282$.

The study was financially supported by the Russian Foundation for Humanities (RFH) project research "Methodological approaches to the monitoring of migration flows for the formation of a management system of quality of life of the population of Siberia and the development of differentiated territorial policy of the country» supporting by Krasnoyarsk regional fund for supporting scientific research and technical research activities, project №15-12-24008.

Research area: economics, sociology.

Prior to build a competency profile of the principal of the municipal educational institutions in the city of Krasnoyarsk we assume that the competency is an ability of the principal to solve tasks in an organizational context successfully (when purpose, the nature of work, organizational structure, intra-regulation, and organizational culture are set beforehand).

There cannot be good and bad competencies, rather they may or may not reflect specific organizational context. For example, when describing the focus of personality, whether he/ she is orientated to the process or the outcome is determined by the conditions of work and arising problems.

Selection of methods for the analysis of competencies is critical due to the necessity of: scientific validity; ability to work online; possibility of generating statistical reports in an automated way; ensuring the compliance of the resulting profile with the evaluation criteria of competence method CAPTain-UTS and the possibility to use this method to evaluate and monitor the competencies of principals of the

(C) Siberian Federal University. All rights reserved

* Corresponding author E-mail address: vip64@mail.ru 
municipal educational institution in the future, to determine the extent of their compliance with the occupied position and their lack of competencies for developing training programs. ADVANCED scales have been designed for professional practice and not for clinical purposes, and are focused on the activities executed by the respondent rather than on the deep structure of the individual.

CAPTain is a computer protected method when the person tested interacts only with a computer, which calculates all the results obtained, so the results of CAPTain test have a high degree of objectivity when conducting and analyzing the data.

The structure of the competencies was determined by us in accordance with the ADVANCED scales, allowing assessing the competencies by 38 scales, subdivided into six subgroups:

- A work style

- B leader qualities

- C making decisions

- D personal characteristics

- E teamwork

- F basic characteristics

Rating scale:

- Low (the very first interval, from 0 to 1 or 2)

- Average (from 3 to 6 or 7)

- High (the last interval, from 7 to 8 or 10 ).

To assess the professional qualities and work style of employees applying for a particular position, one must have a consistent set of criteria for this assessment and determine the desired level of performance for every criterion. The list of criteria and the required level of values by CAPTain scale, which is taken as a model, according to which the results of candidates are compared, is called a profile of job requirements (hereinafter referred to as profile of requirements).
Well made profile of requirements indicates specific of the abilities, qualities and knowledge. It must be sufficiently differentiated and shall describe the required characteristics in detail.

\section{Statement of the Problem}

The researchers created a representative group of experts - principals of the municipal educational institutions of various areas in the city of Krasnoyarsk (totally 23 people).

Testing of experts was made by the procedure called QPD (Questionnaire Profiles of Demands), which is aimed at the classic analysis of works.

The results were discussed in the focus group mode in 2 stages:

Stage 1 - involving all the experts

Stage 2 - the group consisted of 10 principals, who most actively participated in the first round of discussions.

According to the QPD procedure, analytical data describing the principal performance are presented in the form of competencies, including behavioral characteristics, personality traits, knowledge of anti-corruption legislation.

\section{Results}

1. Analysis of targets of school principals, based on the survey of experts (totally 23 people), leads to the conclusion that the principal of the municipal educational institution does not feel as the subject of management, cannot formulate any target and follow the set (hand down) target. The targets were formulated in the style of process terminology and, in most cases they reflect management functions ( $81.3 \%$ of the respondents (Table 1)).

2. In paragraphs describing the principal performance, our experts noted the following positions as the most significant.

The operational tasks dominate $-81 \%$ of respondents, which determined high rates of D5vector. 
Table 1. Examples of answers of school principals in Krasnoyarsk about targets of their activities. The style of the authors is preserved

\begin{tabular}{|c|c|}
\hline $\begin{array}{l}\text { The targets are formulated in style of process terms and } \\
\text { reflect more often management functioning than its results }\end{array}$ & $\begin{array}{l}\text { The targets are formulated in style of process terms and } \\
\text { reflect results partly }\end{array}$ \\
\hline $\begin{array}{l}\text { Management (administration) of learning processes, } \\
\text { recruiting, hiring and management of personnel, } \\
\text { achievement of targets set by the founder. Development of } \\
\text { an organization (need to deliver results better than in any } \\
\text { other similar organizations) } \\
\text { Management of preschool educational institution, solution } \\
\text { of financial problems, strategic planning in the given } \\
\text { institution, settling matters of personnel management, } \\
\text { management of the institution within the regulatory and } \\
\text { legal framework and legislation } \\
\text { Recruitment, allocation of financial resources (budgeting), } \\
\text { decision-making, the motivation of staff } \\
\text { Strategic planning, organization, analysis, stimulation } \\
\text { The general management, the creation of conditions for the } \\
\text { smooth functioning and development of the organization } \\
\text { System management of organi-zation } \\
\text { Educational, enlightening, controlling, organizational } \\
\text { Management of organization } \\
\text { Creation of conditions for the organization activities } \\
\text { Management of the educational process } \\
\text { Keeping position } \\
\text { Management, planning, activity analysis, the } \\
\text { implementation of tasks, creation of conditions for work }\end{array}$ & $\begin{array}{l}\text { The general management of educational organization, } \\
\text { achieving a high quality of offered education, - development } \\
\text { and implementation of a development program of } \\
\text { educational institution, namely personnel selection - } \\
\text { monitoring of development program to ensure safe } \\
\text { conditions of being in the organization } \\
\text { Improving the efficiency of administrative activity } \\
\text { Enhancing the education level pupils-students, development } \\
\text { of solidarity, mutual support, gratefulness to elders. }\end{array}$ \\
\hline
\end{tabular}

The defining feature of the position is the management $-69 \%$. For successful management one needs such qualities as the ability to work with general information and to respond flexibly to the situation, to defend the point of view and to think strategically, to have a fairly high level of readiness to take action. In addition, the manager must be able to build and maintain relationships in the team, setting the general direction of the activities for all employees. Accordingly, there must be low A5indicator and medium D1, E1, $\mathrm{C} 1$ indicators. Indicator A4, given the experts' answers to other questions, has to be average.

Documentation management activity prevails $-50 \%$. This type of activity requires a high degree of attention to detail, clarity and work structuring, the ability to organize and carry out tasks independently. These determine high A3, D5 indicators. But the principal is only responsible for paperwork, but does not do it actually, so the parameters A4 and A5 are low.
The predominant are system tasks $-50 \%$. Unlike routine tasks they require the ability to see the overall direction of all interconnected units (areas, departments), to analyze the extent and quality of their mutual influence on each other. Consequently, there are high indicators by vector D5.

The staff management is also remarkable $-50 \%$. For this kind of activity the ability to interact with people is chief, but, above all, is the willingness of the person to be a leader and take responsibility for the work of employees. This factor determines high indicators by vector F1.

Personal responsibility is decisive $-63 \%$. If the working position requires the ability to take independent decisions, possibly without spending additional time and effort for their finalization and the approval of senior management; to determine the stages of work and set goals, that means that the personal responsibility of this position is high. In this case, you must take into account that 
a person in such a position should consider their relationship with management as a necessary division of responsibilities and functions, rather than as an opportunity to demonstrate their loyalty and dedication. Therefore the researchers got high $\mathrm{A} 8$ indicator and low indicator by vectors B4, F5.

According to experts, the work of the principal of the municipal educational institution implies mostly problems related both to finding solutions to problems $-50 \%$ and the administrative activities. The need to solve the problems arises in different amounts in different workplaces. Any manager solves problems every day, however, the scope of these decisions, the need to find new approaches, or the (organizational, intellectual, communicative) specifications of solutions are different. The ability to solve problems is composed of several skills such as creative thinking, openness to everything new, the ability to stand up for their beliefs and to develop plans for their implementation. In addition, one needs a high intellectual potential and knowledge level, as well as a conceptual approach. The person responsible for finding the way out of problem situations must be prepared for personal responsibility, and therefore must make their own decisions thoughtfully and discreetly, and have sufficient endurance to implement them. Administrative activities, on the contrary, as a rule, require the ability to perform monotonous tasks, accuracy and reasonableness of actions without the desire for innovation. The predominant tasks here are those of practical implementation (75\%) and the need for multi-faceted and multi-level solutions (56\%). This contradictory combination of requirements conditioned the following values of the competencies' vectors - high indicators by A9, A7, A11, D4, F4 vectors, and low indicators by $\mathrm{A} 10$ vector, but the principal is more likely to control over the routine work than to perform it; the description of other activity parameters affecting vector A10 allows to decide in favor of the average value and the average indicator by $\mathrm{C} 1$ vector.

The command tasks dominate (56\%) along with the requirement from the principal to be a leader $(56 \%)$ and to be able to maintain external contacts $(63 \%)$. It is also quite a contradictory combination. Therefore, there should be high indicators by E3, F1, D3 vectors and the average indicator by $\mathrm{E} 5$ vector.

There is high level of engagement in the assessment of the behavior of other people (81\%). Assessing the behavior and abilities of people, or the situation, controlling the quality of work, a person must first be willing to take responsible decisions, and this is a necessary condition for the existence of adequate self-confidence, allowing a critical self-evaluation. Depending on the position and the type of tasks, one must possess such qualities as spontaneous, intuitive making decisions (in the case of interaction with people and the need to respond quickly to the situation in production), or vice versa - a high degree of accuracy and deliberation (for example, in assessing the multi-faceted / multilevel situation). Consequently, there is a high indicator by vector $\mathrm{F} 9$, an average indicator with a tendency to increase by vector $\mathrm{C} 1$, an average indicator by vector E1.

There is a very high need for successful communication in the office, with present almost all kinds of communications. A necessary condition for successful communication of all kinds is the willingness of the person to contact and collaborate, perform teamwork. The more often is a need to make such contacts, the higher is the indicator by F10 vector. There is a certain hierarchy by communication types:

1. negotiating (94\%);

2. speaking in public (94\%)

3. convincing $(75 \%)$

4. exchanging new information (31\%) 


\section{During negotiations}

During the negotiations, an important role is played by the ability to defend one's interests, without losing the personal contact with the negotiating partner and without exerting too much pressure on him/her; what counts is the ultimate desire to agree. Consequently, the indicators by D1 and D3 vectors range from average to high.

To persuade someone in something, one must have considerable power of persuasion, which manifests itself in a clear understanding of their own position, regardless of the correctness of the arguments. What is more, constant effort is required in order to lead others, to demonstrate the ability to maintain good relationships and negotiate. Consequently, the indicators by D1 and E1 vectors range from average to high.

Public speaking requires some inner mentality sets and behavioral skills that allow easy and successful performance and are reflected in the indicator of potential salesman level. The indicator by E2 vector is average, while the indicator by $\mathrm{F} 3$ vector is high.

Quite the opposite qualities are necessary to understand and exchange new information. The indicators by A10 (the need for change) and D4 (willingness to change) vectors range from average to high.

The principal's activities imply, according to experts, that in close contact with a second person or a group there is a need to establish contacts with strangers and to use personal connections in the interests of the organization. The indicators by E5 and E6 vectors range from average to high, while the indicator by E4 vector is high.

\section{The intellectual potential}

Any labor activity presupposes the existence of intellectual potential. However, different job positions assume both a certain level of knowledge (education) and an ability to think scientifically. At different job positions people have to solve problems varying in intellectual level - from a mere choice of several known variants (the level of middle and secondary education) to the creative and scientific approach to finding solutions (level of high education or even several degrees). As a rule, high demands on the intelligence are directly related to the conceptual and theoretical work style (94\%) and set the high level of the indicators by A9 vector (Scheduling).

Difficulty of taken decisions, according to experts, is above average and the high (87\%). The complexity of the decisions depends on how complex / multi-level problems are to be solved, i.e. what number of factors and their interactions one needs to calculate and consider before making a decision. These decisions will affect all employees and all divisions (departments), therefore, the principals need careful planning and foresight; the presence of creative instincts, independence; the search for new solutions and theoretical approach. Obviously, such decision-making requires a calm pace of work. Consequently, the indicator by A6 vector is low, the indicators by Clvector range from average to low, while the indicators by F4 and A9 vectors are high.

Experts believe the work of the principal extremely diverse, with a lot of various tasks that require a high level of flexibility, ingenuity, and individual initiative ( $81 \%$ ). The more varied are the activities, the greater is the need to be proactive and, if possible, to reveal creative abilities, as well as show a high degree of willingness to work with new ideas and actively promote them. Accordingly, the indicator by A10 vector is average and the indicators by $\mathrm{A} 8$ and $\mathrm{F} 4$ vectors are high.

The level of creative abilities should be higher than average (50\%). To explore creativity CAPTain has an independent scale. Very high levels of CAPTain to meet the high demands for creativity, pushing the issues of implementation 
into the background. A creative person does not need to respond readily and with eagerness to the innovations made by others. Nevertheless, there are some operating positions involving both situations. For them, the need for change indicator should vary from average to high level.

The experts noticed quite high level of attention to detail, but the range of opinions is striking, so taking into account the experts' answers to other questions, I suppose that the level of attention to detail has to be from low to average, but mainly low for the head of such level.

The level of self-organization is characterized by experts as the average, so there is a need in rather consistent and structured operating procedure that must be regularly adjusted for current requirements.

High ambitions (50\%), corresponding to the level of $7-8$ by $\mathrm{D} 2$ vector.

The more subordinate employees a candidate for this position is expected to have, the greater his/her leader's potential and the desire to see himself/herself as a leader should be; and the ability to delegate tasks and powers should also be bigger. Due to the fact that $81 \%$ of the experts mentioned the presence of a large number of people subordinate to the principal, the parameters F1, F2 and B2 should be high.

Shared responsibility is recorded at the level from 51 to 250 people, $56 \%$ of the experts. This parameter determines what level of balance and complexity the decision demonstrates; how many people in the company will be affect by the decision taken by a person at this position; the level of managerial abilities. The higher are the quantitative characteristics, the lower are the following indicators: A5, A11, D 5. The indicator by $\mathrm{C} 1$ vector is average.

The experts said that the most important forms of management functions performed by the principal of the municipal educational institution are collective-cooperative one (44\%) and coordinate one $(31 \%)$. The collegial-cooperation style is appropriate for highly qualified and motivated employees, it corresponds to low indicators by $\mathrm{A} 5, \mathrm{~A} 4, \mathrm{C} 1$ vector and average indicators by $\mathrm{B} 1$ and $\mathrm{B} 3$ vectors.

A coordinator (tutor, consultant) management style is good enough to manage the independent personalities; it requires the ability to convince and persuade, while preserving and maintaining relationships. In this case we see the average indicator by D1 vector and the average and high indicators by $\mathrm{E} 1$ vector.

Thus, the profile of competencies of the principal of the municipal educational institution takes the form shown in Fig. 1.

\section{Conclusions}

The character of activities in municipal education implies that the principal of the municipal educational institution functions more likely as the general principal than the entrepreneur.

To perform the set tasks in the present operating context successfully, the principal, according to experts, should demonstrate the aforesaid competencies, which in turn must be built and sustained via monitoring and assessing of competencies by the regional education authorities.

The author's experience in practical application of assessing and monitoring the competencies by CAPTain technology allows us to conclude that this method has the following advantages over traditional manual processes of competency assessment: low labor intensity of evaluation; transparency of assessment procedures; high speed of information flow; the possibility of measuring characteristics, that could be adjusted as a result of training and other forms of work with people; comparability 
Профиль: Директор МОу

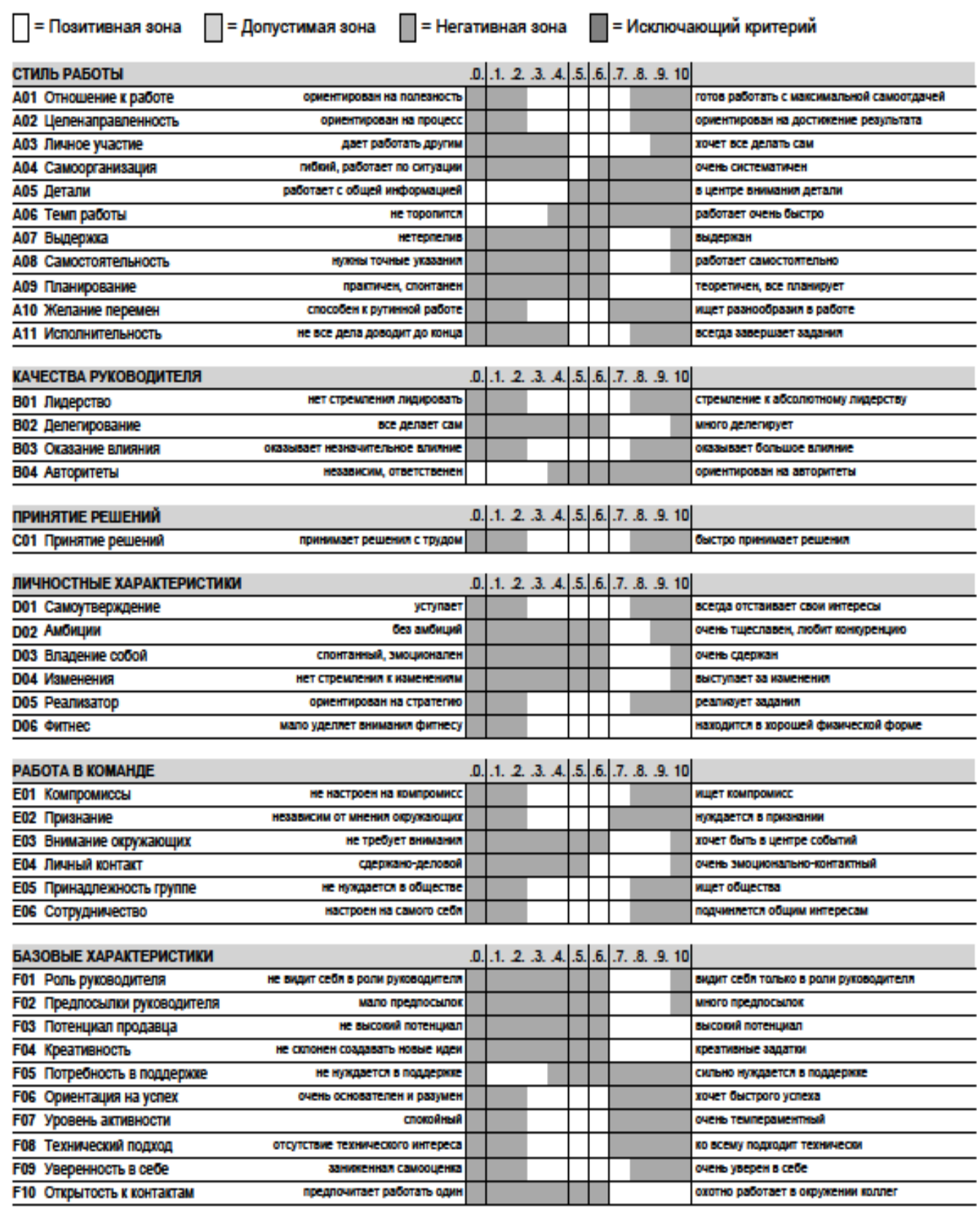

Fig. 1. Profile of the competencies of the principal of the municipal educational institution 
of report formats and the ability to analyze the individual's dynamics quickly; monitoring the process of evaluating competencies is made by the professional community that allows ensuring proper quality of evaluation and control at an acceptable cost.

\title{
References
}

Baranov, A. \& Kakhkharov, Sh. (2007). Sposoby raskrytiia talantov - esli kompanii nuzhny 30,000 zvezd [Methods of spotting talent - if the company needs 30,000 stars], available at: http:// www.classs.ru/hrclub/attestation/attestation17.html (date of reference: 20.11.2014)

Boiatsis, R. Kompetentnyi menedger. Model' effektivnoi raboty. Monografiia. [A competent manager. The model of effective work. Monograph]. Hippo Publishing Ltd, 2008, 352 p.

Khasan,B.I., Novopashina,L.A.\& Vorontsova,I.P.Professional'no-strukturnyeipsikhologicheskie aspekty modeli upravleniia $i$ monitoringa kachestva zhizni $v$ regione [Professionally-structural and psychological aspects of management model and the quality monitoring of life in the region. Krasnoyarsk, Siberian Federal University, 2014, 190 p.

Vorontsova, I.P., Krasnousov, S.D., Tereshkova, V.V. \& Khlonova N.V. Metodika razrabotki korruptsiogennoi karty rabochego mesta rukovoditelia obrazovatel'noi organizatsii [Methodology of development of the workplace corruption card for the head of the educational organization]. Krasnoyarsk, 2015.148 p.

\section{Исследование компетенций директора муниципального образовательного учреждения}

\author{
И.П. Воронцова \\ Сибирский федеральный университет \\ Россия, 660041, Красноярск, пр. Свободныий, 79
}

\begin{abstract}
В статье представлены результаты исследования по формированию профиля компетенщий руководителя мунииипального образовательного учреждения с использованием методики QPD (Questionnaire Profiles of Demands ) и системы Computer Aided Personnel Test (CAPTain), которая позволяет определить пороговые характеристики по ряду критериев готовности к выполнению работы. Исследование выполнено при финансовой поддержке ККФПНиНТД проекта «Разработка коррупциогенной карты рабочего места руководителя муниципального образовательного учреждения (МОУ)».
\end{abstract}

Ключевые слова: компетенщии, образовательная организащия, профиль компетенций, оченка и мониторинг компетенций.

Исследование выполнено при финансовой поддержке РГНФ и Красноярского края проекта проведения научных исследований «Методические подходы к мониторингу миграчионных потоков для формирования системы управления качеством жизни населения регионов Сибири и развития дифференцированной территориальной политики страныр, проект №15-12-24008.

Научная специальность: 08.00.00 - экономические науки, 22.00.00 - социологические науки. 